\title{
THE ANALYSIS OF ABNORMAL RETURN, LIQUIDITY AND STOCK RISK DIFFERENCE DURING PRE AND POST STOCK SPLIT IN IDX PERIOD 2010 - 2014
}

\author{
Umi Mardiyati \\ Fakultas Ekonomi Universitas Negeri Jakarta \\ e-mail:umi.mardiyati@gmail.com \\ Rachmattullah \\ Fakultas Ekonomi Universitas Negeri Jakarta \\ e-mail: wafer0420@gmail.com \\ Gatot Nazir Ahmad \\ Fakultas Ekonomi Universitas Negeri Jakarta \\ e-mail:ahmad72nazir@gmail.com
}

\begin{abstract}
This study aimed to analyze the differences of abnormal return, liquidity and risk stock before and after the stock split on companies listed in Indonesia Stock Exchange 2010 2014. The sample are 29 companies selected by purposive sampling. Period of observations used in this study is 5 days before the stock split and 5 days after the stock split. The analysis technique used is the Kolmogorov-Smirnov test for normality test, paired sample t-test for normally distributed data and Wilcoxon signed rank test if distribution data is not normal. Results from the study showed that there is no significant difference in abnormal returns between before and after stock split period, there are differences in liquidity between the before and after stock split period and there is no difference in stock risk between before and after the stock split period.
\end{abstract}

Keywords : Stock Split, Abnormal Return, Liquidity, Stock Risk 


\section{PENDAHULUAN}

Harga saham mencerminkan nilai suatu perusahaan. Pada tingkat tertentu, harga saham suatu perusahaan dapat menjadi sangat tinggi. Hal ini disebabkan perusahaan yang bersangkutan cenderung memiliki prospek yang baik dimasa depan. Namun, bila harga saham perusahaan terlalu tinggi dapat menimbulkan dampak yang kurang baik bagi perusahaan tersebut karena harga saham yang terlalu tinggi dapat menyebabkan saham tersebut tidak liquid. Harga saham yang terlalu rendah juga sering diartikan bahwa kinerja perusahaan kurang baik. Oleh karena itu, setiap perusahaan yang menerbitkan saham harus memperhatikan harga sahamnya.

Semakin tinggi harga saham, semakin sulit pula para investor untuk membeli saham tersebut. Bagi perusahaan menjalin hubungan yang baik dengan masyarakat dan kepemilikan yang lebih luas sangat diperlukan. Oleh sebab itu, perusahaan ingin memiliki harga saham yang cukup terjangkau sehingga berada dalam batas kemampuan mayoritas calon investor. Untuk mengurangi nilai pasar saham, cara yang biasa digunakan adalah melakukan pemecahan saham atau stock split.

Suatu informasi dianggap informatif atau memiliki nilai apabila informasi tersebut dapat mengubah kepercayaan investor. Reaksi dari adanya informasi tersebut dapat diukur dengan menggunakan return sebagai nilai perubahan harga saham atau menggunakan abnormal return. Maka dapat dikatakan bahwa stock split yang mempunyai kandungan informasi akan memberikan abnormal return.

Likuiditas perusahaan dapat diukur menggunakan bid-ask Spread. Menurut Simatupang, bid price adalah harga saham yang ditawarkan oleh investor publik ketika akan melakukan pembelian saham, sedangkan ask price adalah harga saham yang ditawarkan investor untuk dijual (Mardiyati, 2011). Peristiwa stock split memperbesar kemungkinan bertemunya harga penawaran dan harga permintaan. Semakin kecil bid-ask spread suatu saham maka semakin liquid saham tersebut dan semakin besar bid-ask spread suatu saham semakin tidak liquid saham tersebut. Penelitian Islamiyahya (2012) mengindikasikan bahwa persentase bid-ask spread sebelum pengumuman stock split berbeda secara 
signifikan dengan sesudah stock split. Hal ini ditandai dengan meningkatnya persentase bid-ask spread setelah stock split.

Risiko dapat diartikan sebagai suatu keadaan ketidakpastian, di mana jika terjadi suatu keadaan yang tidak dikehendaki dapat menimbulkan kerugian. Akibat dari stock split jumlah saham yang beredar berubah, kejadian ini menyebabkan para investor yang terpengaruh oleh aktifitas stock split menyusun kembali kegiatan investasinya. Penyusunan tersebut tidak terlepas dari pertimbangan risiko saham.

\section{PERUMUSAN MASALAH}

Berdasarkan latar belakang masalah di atas, peneliti memfokuskan permasalahan yang dapat dirumuskan sebagai berikut:

1. Apakah terdapat perbedaan abnormal return saham sebelum dan sesudah stock split?

2. Apakah terdapat perbedaan bid-ask spread sebelum dan sesudah stock split?

3. Apakah terdapat perbedaan risiko saham sebelum dan sesudah stock split?

\section{TUJUAN PENELITIAN}

Tujuan penelitian ini adalah untuk:

1. Mengetahui apakah terjadi perbedaan abnormal return saham sebelum dan sesudah stock split.

2. Mengetahui apakah terjadi perbedaan bid-ask spread sebelum dan sesudah stock split.

3. Mengetahui apakah terjadi perbedaan risiko saham sebelum dan sesudah stock split.

\section{KAJIAN TEORETIK}

\section{Stock Split}

Hartono mengemukakan bahwa, pemecahan saham atau stock split adalah memecahkan selembar saham menjadi n lembar saham sehingga harga per lembar saham baru setelah stock split adalah selembar $1 / \mathrm{n}$ dari harga sebelumnya (Jogiyanto, 2015). Harga perlembar saham baru setelah stock split adalah sebesar 1/n dari harga sebelumnya. Menurut Brigham dan Houston 
(2011: 234), stock split adalah tindakan yang diambil oleh sebuah perusahaan untuk meningkatkan jumlah lembar saham beredar, seperti menggandakan jumlah lembar saham beredar dengan memberikan dua saham baru kepada pemegang saham untuk setiap satu lembar saham yang sebelumnya dia miliki.

Fahmi dan Hadi memberikan beberapa tujuan suatu perusahaan melakukan stock split (Mardiyati, 2011: 75), yaitu:

a. Untuk menghindari harga saham yang terlalu tinggi sehingga memberatkan public untuk membeli atau memiliki saham tersebut.

b. Mempertahankan tingkat likuiditas saham.

c. Menarik investor yang berpotensi lebih banyak guna memiliki saham tersebut.

d. Menarik minat investor kecil untuk memiliki saham tersebut.

e. Menambah jumlah saham yang beredar.

f. Memperkecil risiko yang akan terjadi, terutama bagi investor yang ingin memiliki saham tersebut dengan kondisi harga saham yang rendah karena sudah dipecah artinya telah terjadi diversifikasi investasi.

g. Menerapkan diversifikasi investasi yaitu sebagai bentuk solusi untuk menghindari risiko dan memperbesar atau menaikan keuntungan.

\section{Abnormal Return}

Abnormal Return adalah selisih antara tingkat keuntungan sebenarnya dengan tingkat keuntungan yang diharapkan. Dalam penelitian ini Abnormal Return $\left(\mathrm{AR}_{\mathrm{it}}\right)$ harian dapat dihitung dengan menggunakan market adjusted model dengan rumus:

$A R_{i t}=R_{i t}-R_{m t}$

Keterangan:
$A R_{i t} \quad=$ abnormal retun sekuritas i pada waktu $\mathrm{t}$
$R_{i t} \quad=$ actual return sekuritas i pada hari ke- $\mathrm{t}$
$R_{m t} \quad=$ return pasar pada hari ke- $\mathrm{t}$ 
Actual return merupakan return yang telah terjadi, penghitungannya dilakukan berdasarkan data historis. Return saham dapat dihitung dengan rumus sebagai berikut:

$$
R_{i t=} \frac{P_{i t}-P_{i t-1}}{P_{i t-1}}
$$

Keterangan:

$\mathrm{R}_{\mathrm{it}} \quad=$ Return saham sekuritas i pada hari ke- $\mathrm{t}$

$\mathrm{P}_{\mathrm{it}} \quad=$ Harga saham sekuritas i pada hari ke-t

$\mathrm{P}_{\mathrm{it}-1} \quad=$ Harga saham sekuritas i pada hari ke $\mathrm{t}-1$

Menurut Jogiyanto (2010: 225) Return pasar $\left(\mathrm{R}_{\mathrm{mt}}\right)$ dapat dihitung sebagai berikut:

$$
R_{m t}=\frac{I H S G_{t}-I H S G_{t-1}}{I H S G_{t-1}}
$$

Keterangan:

$\mathrm{R}_{\mathrm{mt}}$ $=$ Return market pada hari ke-t

$\mathrm{IHSG}_{\mathrm{t}}=$ IHSG harian pada hari ke-t

IHSG $_{\mathrm{t}-1}=$ IHSG harian pada hari ke $\mathrm{t}-1$

Abnormal Return yangpositifmenunjukkantingkatkeuntungan yang diperolehlebihbesardari yang diharapkan.

\section{Likuiditas}

Likuiditas dapat diukur menggunakan tingkat spread. Bid-ask spread merupakan suatu instrumen yang dapat digunakan untuk melihat reaksi pasar modal terhadap informasi melalui parameter perbedaan atau selisih antara harga tertinggi yang diminta untuk membeli dengan harga terendah yang ditawarkan untuk menjual. Menurut Simatupang, bid price adalah harga saham yang ditawarkan olah investor publik ketika akan melakukan pembelian saham, sedangkan ask price adalah harga saham yang ditawarkan investor untuk dijual (Mardiyati, 2011: 77). Sementara Susanti, Arozzy, dan Setiawan mendefinisikan bid price sebagai harga beli yang diminta yang ditentukan oleh dealer, sedangakan ask price adalah harga jual yang diminta 
yang juga ditentukan oleh dealer (Mardiyati, 2011: 77). Spread dirumuskan sebagai berikut:

$$
\% \text { Spread }_{\mathrm{it}}=\frac{A s k_{i t}-\text { Bid }_{i t}}{\left(A s k_{i t}-B_{i d}\right) / 2}
$$

$\%$ Spread $=$ Pesentase Bid-Ask Spread saham i pada hari $\mathrm{t}$

$A s k_{i t}=$ Harga jual terendah saham i pada hari $\mathrm{t}$

Bid $_{i t} \quad=$ Harga beli tertinggi saham i pada hari $\mathrm{t}$

Suatusahamdikatakanberlikuiditastinggijikabid-ask

spread sahamtersebutrendah.

Sebaliknya,

jikabid-ask

spreadtinggimakasahamtersebutberlikuiditasrendah.

\section{Risiko Saham}

Pelaksanaan stock split mengakibatkan jumlah saham yang beredar berubah, hal ini menyebabkan para investor yang berhubungan dengan aktifitas split melakukan kembali penyusunan atas kegiatan investasinya. Penyusunan tersebut tidak terlepas dari pertimbangan risiko saham. Menurut Sutrisno, risiko sebagai variance yaitu nilai deviasi kuadrat (squared deviation) dari rata-rata return saham (Mardiyati, 2011: 77).

$$
\begin{aligned}
& \text { Risiko Saham }=\sqrt{\frac{\sum_{\left(R_{i t}-\bar{R}_{i t}\right)^{2}}^{n-1}}{R}=\text { Rata }- \text { rata return harian } 5 \text { hari sebelum dan sesudah }} \\
& \text { peristiwa stock split } \\
& \quad \text { Return Harian }\left(R_{i t}\right)=\frac{P i_{t}-P i_{t-1}}{P i_{t-1}} \\
& \mathrm{R}_{\text {it }} \quad \text { Return saham i pada hari } \mathrm{t} \\
& \mathrm{P}_{\mathrm{it}} \quad=\text { Harga saham i pada hari } \mathrm{t} \\
& \mathrm{P}_{\mathrm{it}-1} \quad=\text { Harga saham i pada hari ke } \mathrm{t}-1
\end{aligned}
$$

\section{HIPOTESIS}

Berdasarkan landasan teori, penelitian terdahulu, maka hipotesis yang diajukan dalam penelitian ini adalah sebagai berikut:

$\mathrm{H}_{1}$ : Terdapat perbedaan abnormal return saham pada periode sebelum dan sesudah stock split. 
$\mathrm{H}_{2}$ : Terdapat perbedaan likuiditassaham pada periode sebelum dan sesudah stock split.

$\mathrm{H}_{3}$ : Terdapat perbedaan risiko sahampada periode sebelum dan sesudah stock split.

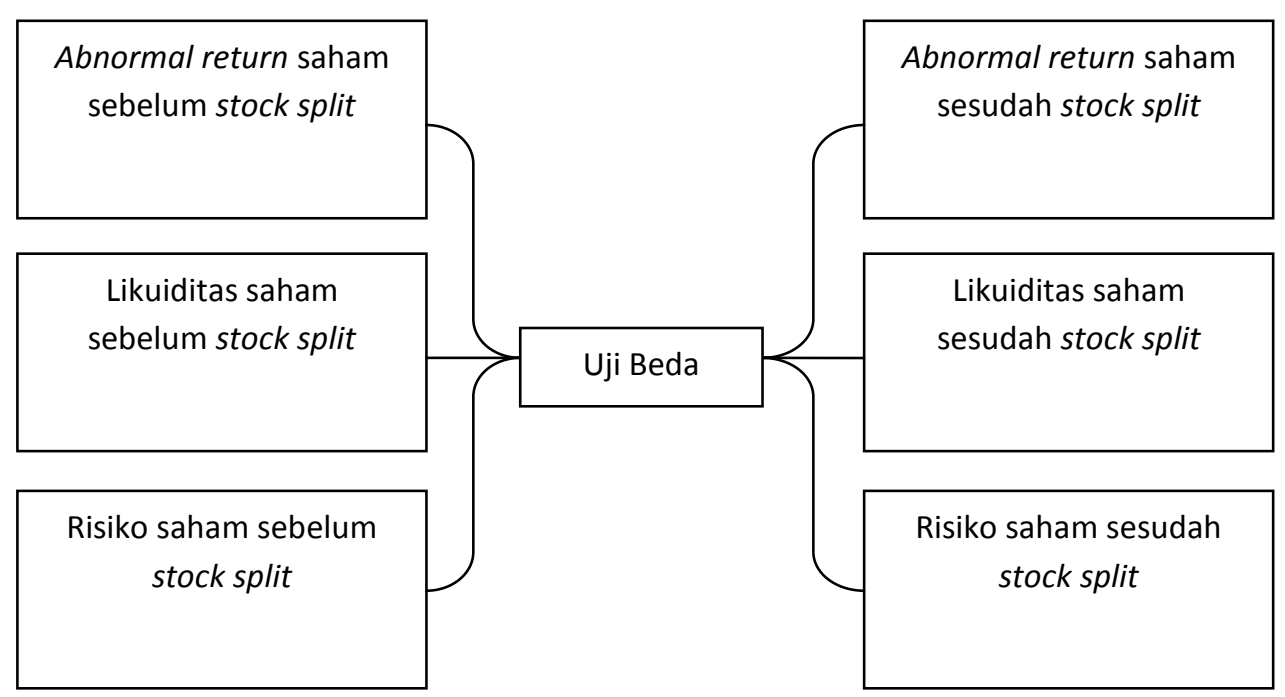

Gambar 1. ModelPenelitian

\section{METODE PENELITIAN}

\section{Populasi dan Sampel}

Malhotra (2010) mengemukakan bahwa populasi ialah jumlah keseluruhan dari semua elemen yang memiliki kesamaan karakteristik serta meliputi keseluruhan obyek atau subjek untuk tujuan masalah dalam penelitian pemasaran. Populasi pada penelitian ini mengacu pada konsumen pengguna backpack di Jakarta Timur. Jenis populasi yang akan diteliti adalah populasi infinite, yaitu objek dengan ukuran yang tidak terhingga (infinite), yang karakteristiknya dikaji atau diuji melalui sampling karena peneliti tidak mengetahui jumlah pengguna backpack di Jakarta Timur.

Malhotra (2010) mengungkapkan bahwa sampel adalah sebuah subgroup dari sebuah elemen populasi terpilih untuk berpartisipasi dalam sebuah studi. Sampel yang Menurut Malhotra sampel ialah subkelompok elemen dari populasi yang dipilih untuk berpartisipasi di dalam sebuah penelitian akan digunakan dalam 
penelitian ini berjumlah 200. Metode sampling yang digunakan dalam penelitian ini adalah purposivesampling. Menurut Sekaran dan Bougie (2010), purposivesampling adalah peneliti memperoleh informasi dari mereka yang paling siap dan memenuhi beberapa kriteria yang dibutuhkan dalam memberikan informasi. Dalam penelitian ini responden yang memenuhi kriteria adalah konsumen backpack yang berdomisili di Jakarta Timur serta mengetahui produk backpack bermerek Consina.

\section{Pengumpulan Data}

Pengumpulan data ini dilakukan melalui pembagian kuesioner kepada responden. Penelitian ini menggunakan skala likert sebagai alat penelitian untuk mengukur pernyataan yang tercantum pada kuisioner. Skala likert yang digunakan dalam penelitian ini menggunakan 5 kategori respons berkisar dari "sangat tidak setuju" sampai "sangat setuju," dimana responden dibutuhkan untuk mengindikasikan sebuah tingkat ketidaksetujuan atau kesetujuan dengan masingmasing seri pernyataan terhubung dengan objek stimulus. Nilai-nilai yang diberikan dari tiap skala adalah:

$\begin{array}{ll}\text { Sangat Tidak Setuju } & \text { Memiliki nilai 1 } \\ \text { Tidak Setuju } & \text { Memiliki nilai 2 } \\ \text { Biasa Saja } & \text { Memiliki nilai 3 } \\ \text { Setuju } & \text { Memiliki nilai 4 } \\ \text { Sangat Setuju } & \text { Memiliki nilai 5 }\end{array}$

\section{METODE PENELITIAN}

Tujuan metode analisis data adalah untuk menginterprestasikan dan menarik kesimpulan dari sejumlah data yang terkumpul. Peneliti menggunakan perangkat lunak atau program SPSS for Windows 20 untuk mengolah dan menganalisis data hasil penelitian. 


\section{HASIL DAN PEMBAHASAN}

\section{Hasil Uji Instrumen}

\section{Uji Validitas}

Validitas menurut Sekaran dan Bougie (2010) ialah ketepatan atau kecermatan suatu instrumen dalam mengukur konsep tertentu. Uji validitas digunakan untuk mengukur sah atau valid tidaknya suatu kuisioner. Uji validitas dalam penelitian ini dilakukan kepada 50 orang responden yang berdomisili di area Jakarta Timur serta mengetahui backpack bermerek Consina. Perhitungan uji validitas dilakukan dengan menggunakan korelasi bivariate pearson (product moment) yang diolah menggunakan software IBM Statistical Product and Service Solution (SPSS) versi 20. Jika $r_{\text {hitung }}>r_{\text {tabel }}(0,279)$, maka instrumen atau item pernyataan berkorelasi signifikan terhadap skor total (dinyatakan valid).

Tabel1.HasilUjiValiditas Variabel Persepsi Kualitas

\begin{tabular}{llll}
$\begin{array}{l}\text { No. Item } \\
\text { pernyataan }\end{array}$ & $\mathbf{r}_{\text {hitung }}$ & $\mathbf{r}_{\text {tabel }}$ & Keterangan \\
\hline $\mathbf{1}$ & 0.733 & 0.279 & valid \\
\hline $\mathbf{2}$ & 0.679 & 0.279 & valid \\
\hline $\mathbf{3}$ & 0.789 & 0.279 & valid \\
\hline $\mathbf{4}$ & 0.486 & 0.279 & valid \\
\hline $\mathbf{5}$ & 0.840 & 0.279 & valid \\
\hline $\mathbf{6}$ & 0.783 & 0.279 & valid \\
\hline $\mathbf{7}$ & 0.825 & 0.279 & valid
\end{tabular}

Sumber: Data diolah peneliti

Tabel2.HasilUjiValiditas Variabel Citra Merek

\begin{tabular}{llll}
$\begin{array}{l}\text { No. Item } \\
\text { pernyataan }\end{array}$ & $\mathbf{r}_{\text {hitung }}$ & $\mathbf{r}_{\text {tabel }}$ & Keterangan \\
\hline $\mathbf{1}$ & 0.692 & 0.279 & valid \\
\hline $\mathbf{2}$ & 0.642 & 0.279 & valid \\
\hline $\mathbf{3}$ & 0.692 & 0.279 & valid \\
\hline $\mathbf{4}$ & 0.621 & 0.279 & valid \\
\hline $\mathbf{5}$ & 0.771 & 0.279 & valid \\
\hline $\mathbf{6}$ & 0.556 & 0.279 & valid \\
\hline $\mathbf{7}$ & 0.632 & 0.279 & valid
\end{tabular}


Tabel3.HasilUjiValiditas Variabel Nilai Emosional

\begin{tabular}{llll}
$\begin{array}{l}\text { No. Item } \\
\text { pernyataan }\end{array}$ & $\mathbf{r}_{\text {hitung }}$ & $\mathbf{r}_{\text {tabel }}$ & Keterangan \\
\hline $\mathbf{1}$ & 0.744 & 0.279 & valid \\
\hline $\mathbf{2}$ & 0.856 & 0.279 & valid \\
\hline $\mathbf{3}$ & 0.847 & 0.279 & valid \\
\hline $\mathbf{4}$ & 0.755 & 0.279 & valid \\
\hline $\mathbf{5}$ & 0.804 & 0.279 & valid \\
\hline $\mathbf{6}$ & 0.780 & 0.279 & valid
\end{tabular}

Sumber: Data diolah peneliti

Tabel4.HasilUjiValiditas Variabel Niat Beli

\begin{tabular}{llll}
$\begin{array}{l}\text { No. Item } \\
\text { pernyataan }\end{array}$ & $\mathbf{r}_{\text {hitung }}$ & $\mathbf{r}_{\text {tabel }}$ & Keterangan \\
\hline $\mathbf{1}$ & 0.616 & 0.279 & valid \\
\hline $\mathbf{2}$ & 0.468 & 0.279 & valid \\
\hline $\mathbf{3}$ & 0.637 & 0.279 & valid \\
\hline $\mathbf{4}$ & 0.541 & 0.279 & valid \\
\hline $\mathbf{5}$ & 0.863 & 0.279 & valid \\
\hline $\mathbf{6}$ & 0.719 & 0.279 & valid \\
\hline $\mathbf{7}$ & 0.733 & 0.279 & valid \\
\hline $\mathbf{8}$ & 0.777 & 0.279 & valid
\end{tabular}

Sumber: Data diolah peneliti

\section{Uji Reliabilitas}

Suatu kuisioner dikatakan reliabel atau handal jika jawaban seseorang terhadap pertanyaan adalah konsisten atau stabil dari waktu ke waktu. Untuk pengujian biasanya menggunakan batasan tertentu seperti 0,6. Jika reliabilitas kurang dari 0,6 adalah kurang baik, sedangkan 0,7 adalah cukup baik, dan 0,8 adalah baik. Berikut ini adalah hasil uji reliabilitas dari masing-masing variabel:

Tabel5.HasilUjiReliabilitas

\begin{tabular}{llll} 
No & Variabel & $\begin{array}{l}\text { Nilai Cronbach's } \\
\text { Alpha }(\boldsymbol{\alpha})\end{array}$ & Keterangan \\
\hline $\mathbf{1}$ & Persepsi Kualitas $(\mathrm{X} 1)$ & 0.854 & reliabel \\
\hline $\mathbf{2}$ & Citra Merek $(\mathrm{X} 2)$ & 0.771 & reliabel \\
\hline $\mathbf{3}$ & Nilai Emosional $(\mathrm{X} 3)$ & 0.881 & reliabel \\
\hline
\end{tabular}




$4 \quad$ Niat Beli (Y) $\quad 0.819 \quad$ reliabel

Sumber: Data diolah peneliti

\section{Hasil Uji Asumsi Klasik}

\section{Uji Normalitas}

Dalam penelitian ini untuk menguji nilai residual digunakan uji One Sample Kolmogorov-Smirnov dengan mengkorelasikan nilai residual (Unstandarized residual) dari masing-masing variabel yang menggunakan nilai signifikan 0,05.

Tabel6.HasilUjiNormalitas

\begin{tabular}{llll} 
No & Variabel & Nilai Signifikansi & Keterangan \\
\hline $\mathbf{1}$ & Persepsi Kualitas (X1) & 0.128 & normal \\
\hline $\mathbf{2}$ & Citra Merek (X2) & 0.086 & normal \\
\hline $\mathbf{3}$ & Nilai Emosional (X3) & 0.061 & normal \\
\hline $\mathbf{4}$ & Niat Beli (Y) & 0.087 & normal
\end{tabular}

Sumber: Data diolah peneliti

\section{Tabel7.HasilUjiNormalitas Residual}

\begin{tabular}{llll} 
No & Variabel & Nilai Signifikansi & Keterangan \\
\hline $\mathbf{1}$ & Persepsi Kualitas (X1) & 0.847 & normal \\
\hline $\mathbf{2}$ & Citra Merek (X2) & 0.352 & normal \\
\hline $\mathbf{3}$ & Nilai Emosional (X3) & 0.317 & normal \\
\hline $\mathbf{4}$ & Niat Beli (Y) & 0.087 & normal
\end{tabular}

Sumber: Data diolah peneliti

Model regresi yang baik adalah model yang memiliki nilai residualnya terdistribusi normal. Pada Tabel 7, berdasarkan uji normalitas residual yang dilakukan pada ketiga model residual, unstandardized residual 1 yang mempengaruhi persepsi kualitas (X1) dengan niat beli (Y), unstandardized residual 2 yang mempengaruhi citra merek (X2) dengan niat beli (Y), dan unstandardized residual 3 yang mempengaruhi nilai emosional (X3) terhadap niat beli (Y), ketiganya memiliki nilai signifikansi melebihi dari $\alpha=0,05$, maka dapat dikatakan nilai ketiga model residual berdistribusi normal.

\section{Uji Linearitas}

Uji linearitas biasanya digunakan sebagai prasyarat dalam analisis korelasi atau regresi linear. Pengujian dapat dilakukan pada taraf signifikasi 0,05. 
Tabel8.HasilUjiLinearitas

\begin{tabular}{llll} 
No & Variabel & Nilai Signifikansi & Keterangan \\
\hline $\mathbf{1}$ & Persepsi Kualitas (X1) & 0.000 & linear \\
\hline $\mathbf{2}$ & Citra Merek (X2) & 0.000 & linear \\
\hline $\mathbf{3}$ & Nilai Emosional (X3) & 0.000 & linear
\end{tabular}

Sumber: Data diolah peneliti

Pada tabel 8 dapat terlihat bahwa ada hubungan yang linear antara variabel bebas terhadap varuabel terikat, karena memiliki nilai signifikansi sebesar 0,000, 0,000 dan 0,000 dimana nilai tersebut $<$ dari 0,05.

\section{Uji Multikolinearitas}

Dalam penelitian ini uji multikolinearitas dilakukan dengan melihat value inflation factor (VIF) pada model regresi. Jika VIF >5, maka variabel tersebut mempunyai persoalan multikolinearitas dengan variabel bebas lainnya.

\section{Tabel9.HasilUjiMultikolinearitas}

\begin{tabular}{llll} 
No & Variabel & Tolerance & VIF \\
\hline $\mathbf{1}$ & Persepsi Kualitas (X1) & 0.463 & 2.161 \\
\hline $\mathbf{2}$ & Citra Merek (X2) & 0.463 & 2.158 \\
\hline $\mathbf{3}$ & Nilai Emosional (X3) & 0.430 & 2.326
\end{tabular}

Sumber: Data diolah peneliti

Pada tabel 9 dapat terlihat bahwa tidak ada hubungan antara variabel bebas, karena memiliki nilai VIF sebesar 2,161, 2,158 dan 2,326 dimana nilai tersebut < dari 5 .

\section{Uji Heteroskedastisitas}

Dalam penelitian ini, uji heteroskedastisitas dilakukan dengan menggunakan uji Glejser, yaitu dengan cara meregresikan variabel bebas terhadap nilai absolute residualnya. Kriteria agar bebas dari heteroskedastisitas ialah apabila nilai signifikansi lebih dari 0,05 (sig > 0,05)

\section{Tabel10.HasilUjiHeteroskedastisitas}

\begin{tabular}{lll} 
No & Variabel & Nilai Signifikansi \\
\hline $\mathbf{1}$ & Persepsi Kualitas (X1) & 0.669 \\
\hline $\mathbf{2}$ & Citra Merek (X2) & 0.994 \\
\hline $\mathbf{3}$ & Nilai Emosional (X3) & 0.942
\end{tabular}

Sumber: Data diolah peneliti 
Pada tabel 10 dapat terlihat bahwa tidak ada gejala heteroskedastisitas, karena memiliki nilai signifikan sebesar 0,669,0,994 dan 0,942 dimana nilai tersebut > dari 0,05 .

\section{Hasil Uji Regresi Berganda}

\section{Uji Regresi Parsial (Uji t)}

Suatu hipotesis dapat dikatakan memiliki pengaruh apabila memenuhi syarat dalam regresi berganda, apabila memiliki nilai signifikan $\leq 0,05$ dan syarat $t_{\text {hitung }}>$ $\mathrm{t}_{\text {tabel, }}$, maka $\mathrm{H} 1, \mathrm{H} 2$ dan $\mathrm{H} 3$ diterima. Berikut adalah hasil uji analisis regresi berganda pada penelitian ini, sebagai berikut :

\section{Tabel11.Hasil Uji t}

\begin{tabular}{llll} 
No & Variabel & $\mathbf{t}_{\text {hitung }}$ & $\begin{array}{l}\text { nilai } \\
\text { signifikansi }\end{array}$ \\
\hline $\mathbf{1}$ & Persepsi Kualitas (X1) & 3.450 & 0.001 \\
\hline $\mathbf{2}$ & Citra Merek (X2) & 3.115 & 0.002 \\
\hline $\mathbf{3}$ & Nilai Emosional (X3) & 8.120 & 0.000
\end{tabular}

Sumber: Data diolah peneliti

Berdasarkan Tabel 11 diketahui bahwa nilai $t_{\text {hitung variabel persepsi kualitas }}$ (X1) adalah sebesar 3,450, variabel citra merek (X2) adalah sebesar 3,115, dan variabel nilai emosional (X3) adalah sebesar 8,120. Nilai signifikansi variabel persepsi kualitas (X1) adalah sebesar 0,001, variabel citra merek (X2) adalah sebesar 0,002 dan variabel nilai emosional (X3) adalah sebesar 0,000. Dengan demikian $t_{\text {hitung }}$ ketiga variabel 3,450,3,115 dan 8,120 $>t_{\text {tabel }}(1,972)$ serta nilai signifikansi ketiga variabel 0,001, 0,002 dan 0,000<0.05. Berdasarkan hasil tersebut, maka artinya ada pengaruh secara parsial antara variabel persepsi kualitas terhadap variabel niat beli, variabel citra merek terhadap niat beli, dan variabel nilai emosional terhadap niat beli.

\section{Uji Regresi Simultan (Uji F)}

Suatu hipotesis dapat dikatakan memiliki hubungan secara bersama-sama apabila memenuhi syarat, dengan tingkat kepercayaan sebesar 0,05 atau $\alpha=0,05$ maka dapat ditentukan dengan melihat nilai signifikansi, dimana nilai signifikan < 0,05 dan syarat $F_{\text {hitung }}>F_{\text {tabel}}$, maka $\mathrm{H} 4$ diterima. 
Tabel 12. Hasil Uji F

\begin{tabular}{|c|c|c|c|c|c|c|}
\hline \multicolumn{7}{|c|}{ ANOVA $^{\text {a }}$} \\
\hline Model & & Sum & of $\mathrm{df}$ & Mean & $\mathrm{F}$ & Sig. \\
\hline \multirow{3}{*}{1} & Regression & 2268,494 & 3 & 756,165 & $\mathbf{1 3 1 , 5 7 0}$ &, $000^{b}$ \\
\hline & Residual & 1126,461 & 196 & 5,747 & & \\
\hline & Total & 3394,955 & 199 & & & \\
\hline
\end{tabular}

Sumber: Data diolah peneliti

Pada tabel 12 dapat terlihat bahwa berdasarkan perhitungan tersebut maka $F_{\text {hitung }}(131,570)>F_{\text {tabel }}(2,650)$ dan nilai signifikansi lebih kecil dari 0,05 atau mempunyai nilai signifikansi 0,000, atau dengan kata lain, terdapat hubungan yang signifikan secara bersama-sama antara persepsi (X1), citra merek (X2) dan nilai emosional (X3) dengan niat beli (Y).

\section{Koefisien Determinasi}

Koefisien determinasi ini menunjukan seberapa besar persentase variasi variabel independen yang digunakan dalam model mampu menjelaskan variasi variabel dependen.

\section{Tabel13.HasilKoefisien Determinasi}

\begin{tabular}{lllll} 
Model R & R Square & $\begin{array}{l}\text { Adjusted } \\
\text { Square }\end{array}$ & $\begin{array}{c}\text { R Std. Error of } \\
\text { the Estimate }\end{array}$ \\
\hline 1 &, $817^{\mathrm{a}}$ &, 668 & $\mathbf{, 6 6 3}$ & 2,397
\end{tabular}

Sumber: Data diolah peneliti

Dari tabel di atas, dapat dilihat bahwa nilai $\mathrm{R}^{2}$ (Adjusted $R$ square) sebesar 0,663 atau $66,3 \%$. Angka ini menjelaskan bahwa variasi variabel independen yang digunakan dalam model, yaitu persepsi kualitas (X1), citra merek (X2) dan nilai emosional (X3) mampu menjelaskan sebesar 66,3\% variasi pada variabel dependen, yaitu niat beli. Sedangkan sisanya 33,7\% dipengaruhi atau dijelaskan oleh variabel lain yang tidak dimasukkan dalam model penelitian ini.

\section{KESIMPULAN DAN SARAN}

\section{Kesimpulan}

1. Hipotesis pertama menyatakan bahwa persepsi kualitas berpengaruh terhadap niat beli diterima karena memiliki nilai $\mathrm{t}$ hitung $3,450>\mathrm{t}$ tabel 
1,972 dengan nilai signifikansi $0,001<5 \%(\alpha=0,05)$. Selanjutnya Persepsi kualitas memiliki pengaruh positif terhadap niat beli karena memiliki nilai koefisien regresi sebesar 0,273.

2. Hipotesis kedua menyatakan bahwa citra merek berpengaruh terhadap niat beli diterima karena memiliki nilai $\mathrm{t}_{\text {hitung }} 3,115>\mathrm{t}_{\text {tabel }}$ 1,972 dengan nilai signifikansi $0,002<5 \%(\alpha=0,05)$. Selanjutnya Citra merek memiliki pengaruh positif terhadap niat beli karena memiliki nilai koefisien regresi sebesar 0,252 .

3. Hipotesis ketiga menyatakan bahwa nilai emosional berpengaruh terhadap niat beli diterima karena memiliki nilai $\mathrm{t}_{\text {hitung }} 8,120>\mathrm{t}$ tabel 1,972 dengan nilai signifikansi $0,000<5 \%(\alpha=0,05)$. Selanjutnya nilai emosional memiliki pengaruh positif terhadap niat beli karena memiliki nilai koefisien regresi sebesar 0,701 .

4. Hipotesis keempat menyatakan bahwa persepsi kualitas, citra merek dan nilai emosional berpengaruh secara bersama-sama terhadap niat beli diterima karena memiliki nilai $\mathrm{f}_{\text {hitung }} 131,570>\mathrm{f}_{\text {tabel }}$ 2,650 dengan nilai signifikansi $0,000<5 \%(\alpha=0,05)$.

\section{Saran}

1. Pihak perusahaan CV Consina Segar Alam sebaiknya menambahkan variasi desain produk backpacknya. Desain yang baik bukan hanya desain yang memiliki tampilan luar yang bagus dan memanjakan mata, namun desain juga harus memberikan kenyamanan saat produk tersebut digunakan.

2. Pihak perusahaan CV Consina Segar Alam harus meningkatkan perhatiannya pada konsumen, seperti melayani setiap pertanyaan dan keluhan konsumen mengenai produk-produk Consina baik melalui layanan call center ataupun melalui akun-akun media sosial milik Consina.

3. Pihak perusahaan CV Consina Segar Alam hendaknya memperluas pasar dengan memperbanyak outlet-outlet resmi dan memperluas distribution channel di berbagai kota, terutama kota-kota yang sering menjadi destinasi wisata outdoor. 
4. Pihak perusahaan CV Consina Segar Alam sebaiknya memperbanyak membuat event yang menarik bagi kalangan pecinta kegiatan outdoor. Seperti kegiatan wall climbing, hiking, pendakian bersama, outdoor run, fun trail dan mendayung yang terbuka untuk masyarakat umum.

5. Pihak perusahaan CV Consina Segar Alam sebaiknya memiliki brand ambassador. Dengan memiliki brand ambassdor, Consina dapat meningkatkan nilai dari merek Consina itu sendiri.

\section{DAFTAR PUSTAKA}

Ahmed, Shehrin. 2014. Bangladeshi Consumers' Purchase Intention toward Global Brands over Local Brands. IISTE ISSN 2224-607X (Paper) ISSN 2225-0565 (Online) Vol.4, No.26

Antyadika, Bonaventura Efrian. 2012. Analisis Pengaruh Lokasi, Harga, Dan Kualitas Produk Terhadap Keputusan Pembelian (Studi pada Wong Art Bakery \& Café Semarang). Universitas Diponegoro. Skripsi.

Asshiddieqi dan Mudiantono. 2012. Analisis Pengaruh Harga, Desain Produk dan Citra Merek terhadap Keputusan Pembelian (Studi Kasus pada Produk Crooz di Distro Ultraa Store Semarang). Diponegoro Journal of Management, Vol 1, No 1

Cahyadi, Imam Febri. 2014. Pengaruh Persepsi Harga, Atribut Produk dan Persepsi Risiko Terhadap Keputusan Pembelian Susu Formula (Studi pada konsumen susu formula SGM di Kota Yogyakarta). Universitas Negeri Yogyakarta. Skripsi.

Cateora, Gilly, dan Graham. 2009. International Marketing 14e. New York: McGraw-Hill Companies, Inc.

Clow dan Baack. 2014. Integrated Advertising, Promotion, and Marketing Communications 6e. USA: Pearson Education Limited

Faraditta dan Mudiantono. 2015. Analisis Pengaruh Country of Origin Perception, Perceived Quality dan Consumer Perception terhadap Purchase Intention 
dengan Brand Image sebagai Variabel Intervening. ISSN 2302 - 9791. Vol. 2 No. 1

Ferdinand, Augusty. 2006. Metode Penelitian Manajemen : Pedoman Penelitian untuk Penulisan Skripsi, Tesis, dan Disertasi Ilmu Manajemen. Semarang: Badan Penerbit Universitas Diponegoro

Gozhali, Imam. 2012. Aplikasi Analisis Multivariate dengan Program IBM SPSS 20. Semarang: Badan Penerbit Universitas Diponegoro

Hawkins dan Mothersbaugh. 2013. Consumer Behavior: Building Marketing Strategy 12e. New York: McGraw-Hill Companies, Inc.

Kapferer, Jean-Noel. 2012. The New Strategic Brand Management : Advanced insights and strategic thinking 5e. London: Les Editions d'Organization

Keegan dan Green. 2013. Global Marketing 7e. USA: Pearson Education Ltd.

Keller, Kevin Lane. 2008. Strategic Brand Management : Building, Measuring, and Managing Brand Equity 3e. USA: Pearson Prentice Hal

Kotler, Philip dan Keller, Kevin. 2015. Marketing Management. $15^{e}$ Global Edition. New Jersey: Pearson Education Ltd.

Kotler dan Armstrong. 2014. Principles of Marketing 15e. USA: Pearson Education, Inc.

Kurtz, David L. 2015. Contemporary Marketing. USA: Cengage Learning

Malhotra, Naresh K. 2010. Marketing Research An Applied Orientation 6e. New Jearsey: Pearson

Marieke de Mooij. 2005. Global Marketing and Advertising: Understanding Cultural Paradoxes 2e. USA: Sage Publications, Inc.

Peter dan Olson. 2010. Consumer Behavior \& Marketing Strategy 9e. Singapore: McGraw-Hill Education Asia 
Poh K. Tee, Behrooz Gharleghi, Benjamin Chan, Behrang Samadi dan Abbas A. Balahmar. 2015. Purchase Intention of International Branded Clothes Fashion among Younger's in Jakarta. International Journal of Business and Social Research, Vol 05, Issue 08

Pratisto Arif. 2004. Cara Mudah Mengatasi Masalah Statistik dan Rancangan Percobaan dengan SPSS. Jakarta: PT. Elex Media Komputindo

Priyatno, Duwi. 2010. Teknik Mudah dan Cepat Melakukan Analisis Data Penelitian dengan SPSS dan Tanya Jawab Ujian Pendadaran. Yogyakarta: Gaya Media

Priyatno, Duwi. 2010. Paham Analisa Statistik Data dengan SPSS. Yogyakarta: MediaKom

Puspitarini, Dian. 2013. Pengaruh Faktor Kebudayaan, Sosial, Pribadi, dan Psikologi Terhadap Proses Keputusan Pembelian Produk Pizza (Studi Pada Pizza Hut Cabang Jalan Jendral Sudirman No. 53 Yogyakarta). Universitas Negeri Yogyakarta. Skripsi.

Sadat, Andi M. 2009. Brand Belief : Strategi Membangun Merek Berbasis Keyakinan. Jakarta: Salemba Empat

Saeednia dan Ghorbanzade. 2014. Factors Influencing Islamic Azad University Students Purchase Intention toward Foreign Apparel Brands. Academic Journal of Research in Business and Accounting Vol. 2, No. 10, December 2014, 63-73, ISSN: 2311-326X

Safarnia dan Mollahosseini. 2013. Iranian Consumers' Purchase Intention toward Global Brands. Interdisciplinary Journal of Contemporary Research in Business Vol 5, No 8

Sarjono dan Julianita. 2011. SPSS vs LISREL, Sebuah Pengantar Aplikasi Untuk Riset. Jakarta : Salemba Empat 
Sarmad, Imran. 2015. Factor Affecting Consumer Purchase Intention toward Multinational Apparel Brands. Journal of Basic and Applied Scientific Research ISSN 2090-4304

Shah I. Shah, Shahzad Akmal, Ahmed Tanvir dan Ahmed Irfan. 2012. Factor Affecting Pakistan's University Students' Purchase Intention Toward Foreign Apparel Brands. Journal of Management Vol. 17

Uma Sekaran dan Roger Bougie. 2013. Research Methods for Business. United Kingdom: John Wiley and Sons Ltd.

Umboh O. Sisilia, Tumbel Altje dan Soepeno Djurwati. 2015. Analisa Kualitas Produk, Brand Image dan Life Style terhadap Keputusan Pembelian Pakaian Wanita di Mississippi Mando Town Square” Jurnal EMBA Vol.3 No.1 Maret 2015, Hal. 1096-1105, ISSN 2303-1174

Vikkraman dan Sumathi. Purchase Behaviour in Indian Apparel Market: an Analysis. ZENITH International Journal of Business Economics \& Management Research, Vol.2 Issue 2, ISSN 2249 8826, February 2012.

Deuter. Our History. http://www.deuter.com/DE/en/about-deuter.html (Diakses pada tanggal 21 Januari 2017)

Google trends. Trend Consina, Eiger, Deuter, Avtech, Cozmeed 2011-2016. www.google.com/trends/ (Diakses pada tanggal 28 Agustus 2016)

Sciencedirect. Perjuangan Dyson Merangsek Pasar Outdoor. http://www.sciencedirect.com/science/article/pii/S0148296308001665 (Diakses pada tanggal 28 Maret 2016)

Swa. Ini Resep Eiger Kuasai Pasar. http://swa.co.id/swa/trends/marketing/iniresep-eiger-kuasai-pasar (Diakses pada tanggal 21 Januari 2017. 